\title{
ILMU SEBAGAI SUBSTANSI DA'WAH DALAM ISLAM
}

\author{
DOI: https://doi.org/ $\mathrm{xxxxx \times x}$
}

\author{
UJANG HABIBI \\ hanunbibi@yahoo.co.id \\ STID Mohammad Natsir, Indonesia
}

\begin{abstract}
ABSTRAK
Tujuan penelitian ini untuk mengetahui kedudukan ilmu sebagai substansi da'wah dalam Islam. Metode penelitian menggunakan kualitatif. Hasil dalam artikel ini menunjukkan bahwa Islam menjunjung tinggi ilmu, baik ilmu itu sendiri maupun orang-orang yang menekuni ilmu, mengerahkan tenaga dan waktunya untuk menggali ilmu. Karena begitu pentingnya ilmu sehingga Allah menyebutkan kata ini sampai beratus-ratus kali. Bagi Islam, sumber ilmu yang paling benar adalah dari alQur'an dan hadits yang shahih, sehingga bagi seorang muslim pun harus menyandarkan ilmu nya kepada keduanya dan melandasinya dengan konsep aqidah atau tauhid yang kokoh kepada Allah sebagai sumber ilmu yang absolut.
\end{abstract}

Kata kunci: ilmu, Islam, da'wah

\section{PENDAHULUAN}

Ilmu dalam Islam menempati posisi sangat penting. Salah satu indikasinya adalah al-Qur'an menyebut kata 'ilm dan derivasinya sebanyak 750 kali. Sehingga orang berilmu menempati posisi mulia, niscaya Allab akan meninggikan orang-orang yang beriman di antaramu dan orang-orang yang diberi ilmu pengetabuan beberapa derajat. dan Allah Maha mengetahui apa yang kamu kerjakan. (Qs. Al-Mujadilah: 11). Dalam Islam, ilmu terkait dengan akidah. Syeikh Abdul Qohir al-Baghdadi misalnya mengatakan; "Pilar pertama (dari ciri akidah Ablussunnah wal Jama'ah) adalah menetapkan realitas dan ilmu" Syed Muhammad Naquib al-Attas mengatakan "... Islam adalah agama yang berdasarkan ilmu pengetahuan. Penyangkalan terhadap kemungkinan dan objektifitas ilmu pengetahuan

1 Abdul Qohir al-Baghdadi, Al-Farqu Bainal Firaq, Beirut: Dar al-Kutub al-Ilmiyah, tanpa tahun, hlm. 249 
akan mengakibatkan hancumya dasar yang tidak banya menjadi akar bagi agama, tetapi juga bagi semua jenis sains". ${ }^{2}$

Karena begitu banyaknya term ilmu yang disebutkan dalam al-Qur'an, maka dalam makalah ini hanya akan dipaparkan beberapa ayat saja untuk menjelaskan makna ilmu tersebut.

Ilmu bermakna pengetahuan; menjadi bantahan terhadap alasan dari kesyirikan orang-orang musyrik (Qs. Al-An'am: 148)

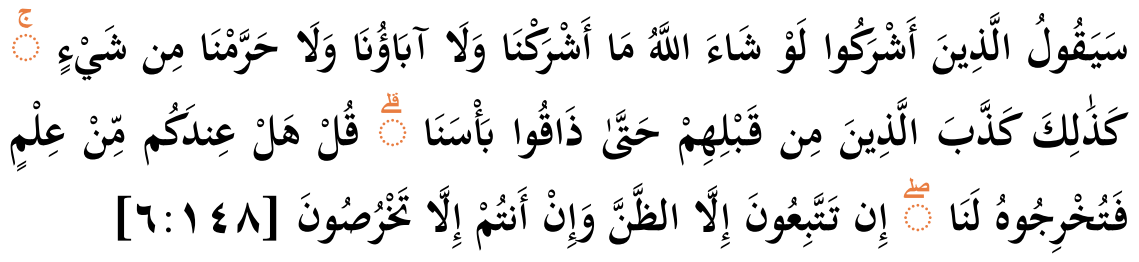

Orang-orang yang mempersekutukan Tuhan, akan mengatakan: "Jika Allah menghendaki, niscaya kami dan bapak-bapak kami tidak mempersekutukan-Nya dan tidak (pula) kami mengharamkan barang sesuatu apapun". Demikian pulalah orang-orang sebelum mereka telah mendustakan (para rasul) sampai mereka merasakan siksaan Kami. Katakanlah: "Adakah kamu mempunyai sesuatu pengetahuan sebingga dapat kamu mengemukakannya kepada Kami?" Kamu tidak mengikuti kecuali persangkaan belaka, dan kamu tidak lain hanyalah berdusta. (QS. 6: 148)

\section{Tafsir Ayat}

$$
\begin{aligned}
& \text { سيقول الذين أشركو لوأراد الله أن لا نشرك ـ نخن و آباؤنا ـ و أن لا شخرم شيأ } \\
& \text { من دونه ما فعلنا ذالك, وردّ الله عليهم ببيان أن هذه الشببهة قد أثرها } \\
& \text { الكفار من قبلهم, وكذّبوا بها دعوت رسلهم, و استمرٌٌ واعلى ذلك, حتى } \\
& \text { نزل بهم عذاب الله . قل لمم ـ أيها الرسول . هل عندكم ـ فيما حرّمتم من } \\
& \text { الأنعام و الحرث, و فيما زعمتم من أن الله قد شاء لكم الكففر , ورضيه منكم }
\end{aligned}
$$

2 Wan Mohd Nor Wan Daud, Epistemologi Islam dan Tantangan Pemikiran Umat,dalam Jurnal Islamia No. 5 Thn II April-Juni 2005, hlm. 52 


\section{و أحبه لكم ـ من علم صحيح فتظهروه لنا؟ إنتتبعون في أمور هذالذين الا مجرد الظن, و إن أنتم إلا تكذبون}

Akan berkatalah orang-orang yang menyekutukan Allah, jikea Allab menghendaki maka kami tidak akan mempersekutukan Allah, - kami dan juga bapak-bapak kamil orang-orang sebelum kami. Dan kami tidak mengharamkan sesuatu pun selain dari apa yang Allah perintabkan, kami tidak akan melakukannya, dan Allah membalas/ menjawab atas mereka dengan penjelasan babwa sesunggubnya syubhat merka ini telab pula di sampaikan oleh orang-orang kafir sebelum mereka dan mereka telab mendustakan dengannya yaitu seruan rasul-rasul yang diutus kepada mereka. Dan mereka terus menerus berada dalam perbuatan mendustakan rasul dan mengharamkan tersebut sampai turun kepada mereka adzab Allah. Maka, katakanlah kepada mereka wahai rasul, "Apakah disisi kalian pada apa-apa yang kalian haramkan dari bewan ternak dan tanaman dan pada apa-apa yang kalian duga bahwasanya Allab sunggub menginginkan bagi kalian kekufuran dan meridhai kekafiran itu dari kalian dan mencintai kekafiran itu bagi kalian berupa ilmu yang benar maka tampakkanlah ilmu tersebut bagi kami sekiranya kalian mengikuti pada urusan-urusan agama ini. Babkan kalian hanya sekadar menyangka belaka dan kalian tidak lain kecuali hanya berdusta."

Ayat di atas tengah bercerita tentang perdebatan yang Allah SWT. sebutkan, dan juga syubhat yang dijadikan sandaran oleh orang-orang musyrik dalam membenarkan kemusyrikan mereka, serta pengharaman terhadap apa yang mereka buat-buat sendiri. (Menurut mereka) sesungguhnya Allah mengetahui kemusyrikan dan pengharaman yang mereka lakukan itu, dan sebenarnya Allah mampu untuk mengubah hal itu dengan mengilhamkan keimanan kepada mereka, serta menghindarkan mereka dari kekufuran tersebut. Namun Allah tidak mengubahnya, maka menurut klaim mereka, hal tersebut menunjukkan bahwa kemusyrikan ini tidak lain berdasarkan kehendak dan keinginanNya, dan Allah pun meridhai mereka melakukan hal tersebut. $^{4}$

Jenis syubhat ini menurut Ahmad bin Mustafa al Maraghi, sekalipun belum dikatakan oleh orang-orang musyrik itu dan belum mereka nyatakan kepada Rasul Shallallahu 'Alaybi W asallam namun Allah yang ilmunya meliputi segala sesuatu, tahu bahwa mereka akan mengucapkannya. Maka oleh Allah

3 Sholeh ibn Abdul Azis bin Muhammad Alu Syekh et al, Tafsir al-Muyassar, Percetakan al-Qur'an Kerajaan Saudi Arabiah, 1430 H/ 2009 M, hlm.148

4 Abdullah bin Muhammad bin 'Abdurrahman bin Ishaq Alu Syaikh, Lubaabut Tafsir Min Ibni Katsïr (Terj.), jilid 1, Jakarta: Pustaka Imam Syafi'i, 2012, hlm. 398 
syubhat ini disebutkan dan dijawab pula dengan jawaban yang membantah. Hal itu termasuk berita-berita dari Allah tentang perkara-perkara ghaib yang belum terjadi. ${ }^{5}$

Semakna dengan ayat tersebut, ialah firman Allah Ta'ala dalam surah an-Nahl (16) ayat 35:

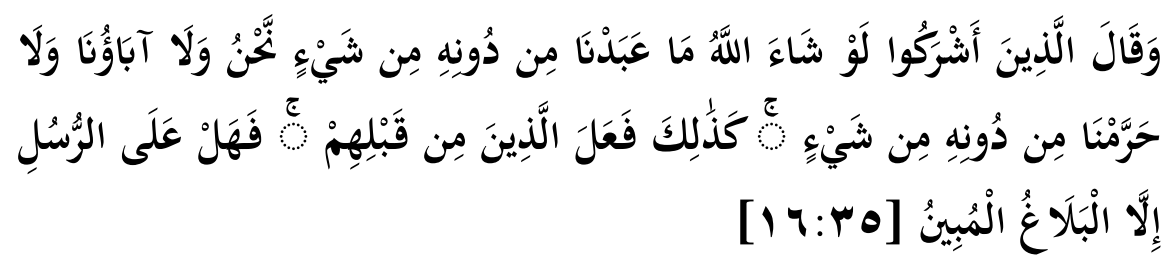

Dan berkatalah orang-orang musyrik: "Jika Allah menghendaki, niscaya kami tidak akan menyembah sesuatu apapun selain Dia, baik kami maupun bapak-bapak kami, dan tidak pula kami mengharamkan sesuatupun tanpa (izin)-Nya". Demikianlah yang diperbuat orang-orang sebelum mereka; maka tidak ada kewajiban atas para rasul, selain dari menyampaikan (amanat Allah) dengan terang.

Demikian pula disebutkan dalam surah az-Zukhruf (43) ayat 20:

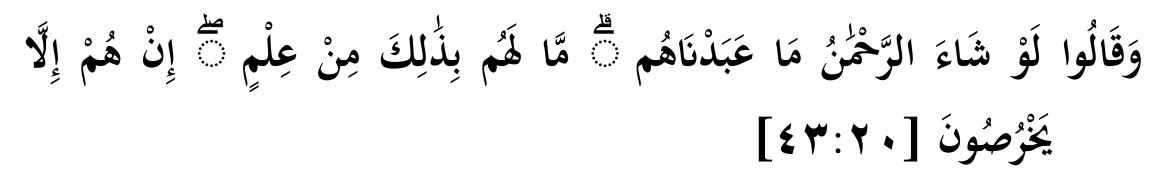

Dan mereka berkata: "Jikalau Allah Yang Maha Pemurab menghendaki tentulah kami tidak menyembah mereka (malaikat)". Mereka tidak mempunyai pengetabuan sedikitpun tentang itu, mereka tidak. lain hanyalah menduga-duga belaka.

Mafhum daripada jawaban orang-orang yang mempersekutukan Allah dalam ayat tersebut ialah jika mereka mempersekutukan Allah dengan yang lain, tidaklah itu atas kehendak mereka, melainkan takdir dari Allah sendiri.... kalau Allah tidak menghendaki, tentu tidak akan terjadi demikian. Maka datang pula sambungan ayat: "Demikian pulalah orang-orang sebelum mereka telah mendustakan (para rasul)." Artinya suara-suara seperti ini bukan sekarang saja, bahkan orang-orang dahulu, umat nabi-nabi yang dahulu pun pernah, jika mereka terdesak dalam perbuatannya yang karut, mereka melepaskan diri dengan menyandarkannya kepada takdir. "Kalau bukan kehendak Tuban, tidaklah kami akan begini.

${ }^{5}$ Ahmad Mustafa al-Maraghi, Tafsir al-Maraghi, Semarang: CV. Toha Putra, 1992, hlm.

${ }^{6}$ Hamka, Tafsir Al-Az̧har, Juzu’3, Kerjaya Printing Industries Pte Ltd, 2003 hlm, 2234 
Lebih lanjut, menurut Hamka, apa yang dkatakan dalam al-Qur'an ini. Menyandarkan sesuatu kelemahan kepada takdir bukanlah timbul dalam kalangan kaum musyrikin Quraisy di zaman rasulullah Shallallabu 'Alaybi Wasallam saja, tetapi sudah lama dari dahulu dari itu. Dalam kalangan penganut agama Nashrani sudah lama jadi perbincangan tentang takdir dan ikhtiar. Faham determinisme dengan Indeterminisme, bebaskah manusia di dalam hidupnya ataukah dia terkungkung oleh suatu yang telah ditentukan, sehingga gerak-geriknya terbatas. ${ }^{\top}$

Dalam ayat ini nampak sekali bahwa di zaman jahiliyah itu golongan musyrikin mengambil takdir menjadi tempat lari dari tanggungjawab. Alasannya, telah habis, ketika ditanya tidak dapat memberikan jawaban. Lalu setelah terdesak keluar pengakuan bahwa kalau bukan kehendak Tuhan, tidaklah mereka akan begitu.

Maka, datanglah sambungan ayat: "Sehingga mereka merasakan siksaan Kami." Artinya, bahwasanya lari menyembunyikan muka ke dalam suasana takdir, padahal selama ini Tuhan Allah didurhakai adalah membuat Tuhan Allah murka.

Mengapa engkau lari kepada takdir saja, padahal engkau sadari sendiri bahwa engkau telah diberi akal buat menimbang buruk dan baik? Mengapa engkau tidak duduk saja dalam rumah, tidak usah berusaha ke mana-mana? Karena kalau sudah takdir Tuhan, niscaya rezeki makan dan minum akan datang sendiri ke dalam rumahmu, langsung masuk mulutmu? Mengapa tidak engkau tunggu saja? Tentu engkau sendiri akan menjawab bahwasanya engkau masih berusaha mencarinya, karena belum pernah Tuhan Allah mentakdirkan makanan langsung masuk mulut kalau tidak dijemba dengan jari dan dicari menurut hukum sebab akibat. ${ }^{8}$

Di dalam ayat ini ditegaskan bahwasanya jawaban, "Kalau Allah menghendaki tidaklah mereka akan mempersekutukan Tuban, dan tidak, pula nenekmoyang mereka dabulu-dabulu akan mempersekutukan Tuban," menurut Buya Hamka dalam tafsir Al-Azhar-nya adalah jawaban kaum musyrikin jahiliyah, dan demikian juga jawaban orang-orang dahulu, orang yang hendak ingkar dari tanggungjawab. Bahkan demikian juga jawaban orang sekarang, setelah Nabi Muhammad Shallallabu 'Alaybi Wasallam diutus dan setelah argumen' itu dikritik dalam al-Qur'an. Faham jabariyyah, yaitu bahwa jika nasibku begini sekarang ini, jika aku jatuh hina, jika umat Islam beratus tahun lamanya

${ }^{7}$ Ibid.

${ }^{8}$ Ibid. hlm. 2235

${ }^{9}$ Dalam tafsir al-Azhar, Hamka menulis, "Setelah Nabi Muhammad s.a.w. diutus dan setelah senjata itu dikritik dalam al-Qur'an.” (perubahan kata senjata menjadi argumen adalah oleh penulis makalah ini) Lihat, Ibid. 
menjadi anak jajahan, semuanya itu adalah takdir yang mesti diterima. Kalau kita bodoh, ialah takdir! Kalau si Fulan dihukum lalu masuk penjara, demikianlah takdir ilahi. ${ }^{10}$

Sikap mempertahankan hawa nafsu, lalu mengambil takdir sebagai alasan untuk bersembunyi atau yang disebut Hamka sebagai penyakit jabariyah ini menular kepada umat Islam sendiri, umat yang mengaku dirinya umat Muhammad Shallallahu 'Alaybi 'asallam di zaman kemundurannya. Hamka juga mengutip tulisan Sayid Jamaluddin al-Agfhani di dalam surat kabar al-Urwatul Wutsqa yang terbit di Paris tentang al-Qadha dan al Qadar. Bahwasanya kepercayaan terhadap takdir adalah rukun (tiang) keenam dalam aqidah dan imannya seorang Muslim. Apabila iman bertambah tinggi mutunya, sehingga menimbulkan roh atau semangat dan menimbulkan nur atau cahaya, pastilah kepercayaan kepada takdir jadi pendorong buat berani menempuh hidup. Al-Afghani sebagaimana dikutip Hamka mengatakan bahwa, salah satu sebab kemenangan Islam dan ajaran Islam membanjiri dunia dalam masa seperempat abad saja, lain tidak ialah karena kepercayaan kepada takdir. Pejuang-pejuang, Mujahidin yang menyerbu ke medan perang, meruntuhkan parit-parit pertahanan musuh yang teguh, sehingga menaklukkan semenanjung Iberia di Barat dan sungai Indus di Timur, adalah karena Mujahidin itu percaya kepada takdir, bahwa kalau tidak mati kata Allah, tidaklah akan mati, walaupun dalam penyerbuan itu pedang musuh telah berkilatan sekeliling leher. Sebaliknya setelah iman itu menurun, mundur, redup dan kemudian padam, sehingga Islam hanya tinggal nama, datanglah penyakit jabariyah (nasibku yang malang adalah takdir Allah). "Dan kalau tidak atas kehendak. Allah, tidaklah nasibku akan begini!" Dan sebagainya. ${ }^{11}$

Tersebut 62 (enampuluh dua) sebab kemunduran kaum Muslimin yang dilukiskan oleh Sayid Abdurrahman el-Kawakibi sebagaimana dikutip Hamka dalam tafsirnya, satu diantaranya adalah faham jabariyyah ini. ${ }^{12}$

Maka, orang Musyrikin yang bertahan, "Kalau bukan kehendak Allah, tidaklah kami akan begini." Yaitu jawaban orang lemah di zaman dahulu, dan orang lemah sampai zaman sekarang, tidaklah dapat mengemukakan alasan yang ilmiah, yang masuk akal, yang dapat diberikan dan yang memuaskan.

Sudah pasti bahwa mereka tidak dapat mengemukakan alasan tepat. Sebab agama mereka bukan dari akal, bukan dari ilmu dan bukan sama sekali dari wahyu. Sebab itu datanglah kepastian dari ayat selanjutnya, "Tidak ada yang kamu ikuti kecuali sangkaan-sangkaan dan tidaklah kamu ini, melainkan berdusta semua." (ujung ayat 148 surah al-An'aam).
${ }^{10} \mathrm{Ibid}$.
${ }^{11}$ Ibid. hlm. 2236
12 Ibid. 


\section{Tafsir Kata Ilmu}

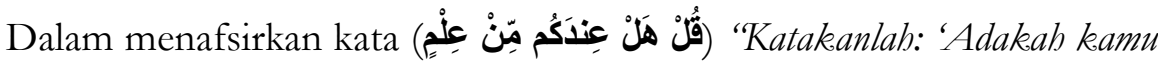
mempunyai suatu ilmu/pengetabuan." Maksudnya adalah bahwa Allah benarbenar memberikan keridhaan atas apa yang kalian kerjakan tersebut. ${ }^{13}$ Pertanyaan ini tidak diragukan lagi, menurut al-Maraghi, merupakan penghinaan dan ejekan.

Katakanlah, apakah dengan perkataanmu itu kamu mempunyai ilmu yang kamu jadikan sandaran dan hujjah, sehingga kamu keluarkan ilmu itu pada kami supaya kami memahami dan pertimbangkan antara ilmumu itu dengan ayat-ayat logis dan kejadian-kejadian yang telah kami datangkan kepadamu, yang menceritakan tentang umat sebelum kamu, dan biarlah jelas bagi kami, manakah diantara itu semua yang lebih kuat dan mana pula yang lemah? ${ }^{14}$

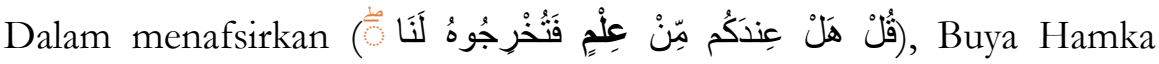
menulis:

Adakah pada kamu satu ilmu bahwasanya kamu sudah ditentukan akan sengsara, sebab itu kamu tidak usah berikhtiar lagi? Kamu sudah ditentukan memang untuk menjadi musyrik, sebab itu tidak perlu lagi mendengar ajaran Rasul tentang Tauhid? Tidak ada! Ilmu itu tidak ada. Tidak pernah Allah memberi tahu nasib seseorang akan malang, nasib seseorang akan tetap menjadi kafir. Yang terang dan tegas diberitahukan Allah dengan perantaraan Rasul-rasulNya, hanyalah seseorang diperintah percaya kepada Allah, diperintah mengerjakan yang baik dan menjauhi yang buruk. Diperintah beriman dan beramal, berusaha. ${ }^{15}$

Kemudian Allah SWT. melanjutkan dengan menerangkan hakikat

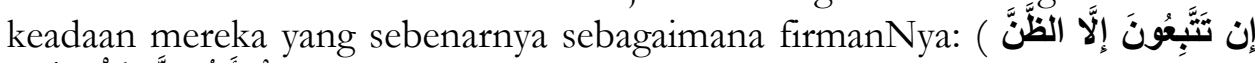
Sesungguhnya kalian sedikit pun tidak berilmu. Bahkan akidahmu dan pendapat-pendapatmu tentang agama dan pengamalan kalian

\footnotetext{
${ }^{13}$ Abdullah bin Muhammad Alu Syaikh, Lubaabut Tafsir Min Ibni Katsiir (Terj.) jilid 1,

14 Ahmad Mustafa al-Maraghi, Tafsir al-Maraghi, hlm. 106

${ }^{15}$ Hamka, Tafsir Al-Az̧har, Juzu' 3, hlm, 2235
} hlm. 399 
hanyalah mengikuti dugaan dan terkaan belaka, yang tidak memberikan kepastian hukum. ${ }^{16}$

Pelajaran dari umat-umat terdahulu yang telah Allah binasakan (Qs. Al-A'raf: 7)

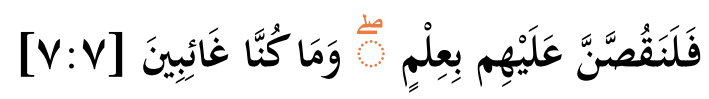

Maka sesunggubnya akan Kami kabarkan kepada mereka (apa-apa yang telab mereka perbuat), sedang (Kami) mengetahui (keadaan mereka), dan Kami sekali-kali tidak jauh (dari mereka). (QS. 7:7)

\section{Tafsir Ayat}

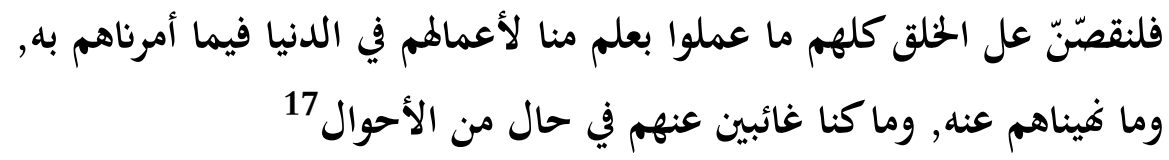

Maka sungsub benar-benar akan kami kisabkan atas makbluk semuanya. Apa-apa yang telah dikerjakan dengan ilmu dari kami untuk amalanmalan mereka di dunia pada apa-apa yang kami telah perintabkan mereka dengannya dan apa-apa yang telah kami larang mereka darinya. Dan tidaklah (kata Allah) kami alpa atas apa yang mereka lakukan atas apa saja yang mereka lakukan.

Kata al Qassu dari ayat di atas berarti mengikuti jejak dengan perbuatan, sebagaimana yang tercantum dalam firman Allah Ta'ala yang mengisahkan tentang ibu Nabi Musa 'Alaibissalam dalam surah al-Qashash (28) ayat 11:

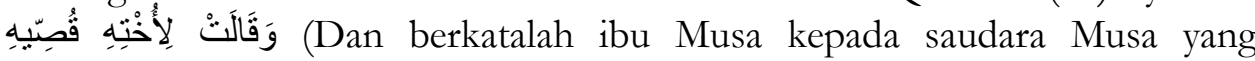
perempuan: "Ikutilah dia"). Bisa juga dengan perkataan sebagaimana yang terkandung dalam firman Allah Ta'ala dalam surah Yusuf (12) ayat 3: نَحْنُ نَقُْصن عَلَيْمَ أَحْسَنَ الْقَصَصِ (Kami menceritakan kepadamu kisah yang paling baik). ${ }^{18}$

Maksud ayat di atas menurut al-Maraghi bahwa segala yang terjadi pada kedua belah pihak, berupa suatu kisah dengan ilmu dari Allah yang meliputi

\footnotetext{
${ }^{16}$ Ahmad Mustafa al-Maraghi, Tafsir al-Maraghi, hlm. 106

${ }^{17}$ Sholeh ibn Abdul Azis et al, Tafsir al-Muyassar, hlm.151

18 Ahmad Mustafa al-Maraghi, Tafsir al-Maraghi, hlm. 184
} 
segala yang pernah terjadi dari mereka, takkan terlewatkan dariNya seberat zarrah pun. ${ }^{19}$

Berkenaan dengan ayat di atas, Ibn Abbas radhiyallabu 'anbu, sebagaimana disebutkan dalam Lubaabut Tafsir Min Ibni Katsiir mengatakan: "Buku catatan akan diletakkan pada hari kiamat kelak, maka buku catatan itu pun akan berbicara mengenai apa yang mereka kerjakan."

Allah SWT. memberitahu hamba-hambaNya pada hari kiamat kelak, mengenai apa yang telah mereka ucapkan dan kerjakan, baik yang berjumlah sedikit, banyak, yang bertumpuk-tumpuk, maupun yang hina, karena Allah Mahamenyaksikan segala sesuatu. Tidak ada sesuatu pun yang tersembunyi dariNya dan tidak pula Allah lengah dari sesuatu, bahkan Allah Mahamengetahui pandangan mata yang khianat dan apa yang tersembunyi di dalam hati. ${ }^{20}$

Maksud dari ayat tersebut menurut al-Maraghi, yaitu sesungguhnya Allah menceritakan kepada rasul-rasul dan kepada kaum mereka masingmasing; yang kepada mereka rasul-rasul itu telah diutus. Segala yang terjadi pada kedua belah pihak, berupa suatu kisah dengan ilmu dari Allah yang meliputi segala yang pernah terjadi dari mereka, takkan terlewat dari Allah seberat zarrah pun. ${ }^{21}$

Apabila pemeriksaan telah datang kelak di hari kiamat, tidaklah seorangpun yang sanggup berdusta atau mengelak diri dari tanggungjawab. Sebab apa yang kita sembunyikan, Allah mengetahuinya. Apa yang kita lupa, Allah tetap mengingatnya. Kita diperiksa adalah dengan pengetahuan.Allah mengetahui segala gerak-gerik kita di kala hidup. Yang jujur ataupun yang curang Dia tahu. Catatan ada pada sisi Allah, dan Allah tidaklah ghaib dari sisi kita. $^{22}$

Ilmu sebagai petunjuk (Qs. Al-A'raf: 52)

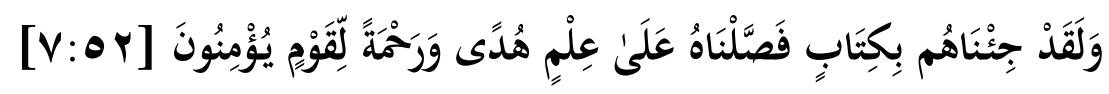

${ }^{19} \mathrm{Ibid}$.

${ }^{20}$ Abdullah bin Muhammad Alu Syaikh, Lubaabut Tafsir Min Ibni Katsiir, jilid 1, hlm. 439

${ }^{21}$ Ahmad Mustafa al-Maraghi, Tafsir al-Maragbi, hlm. 184.

${ }^{22}$ Hamka, Tafsir Al-Az̧har, Juzu’ 4, Kerjaya Printing Industries Pte Ltd, 2003 hlm, 2317

81 | Dakwah | Vol 4 | No. 1 | 2021 
Dan sesunggubnya Kami telah mendatangkean sebuah Kitab (Al Quran) kepada mereka yang Kami telah menjelaskannya atas dasar pengetabuan Kami; menjadi petunjuk dan rahmat bagi orang-orang yang beriman. (QS. 7:52)

\section{Tafsir Ayat}

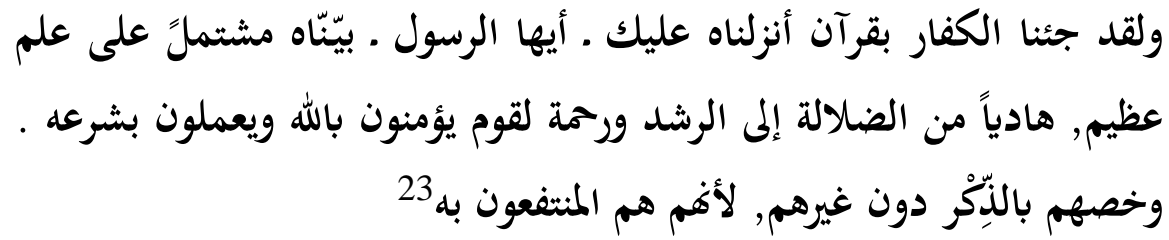

Dan sungguh kami datangkan bagi orang kafir dengan al Qur'an yang kami turunkan kepadamu wabai Mubammad, kami jelaskan kepadamu melingkupi dengan sempurna atas ilmu yang agung sebagai pemberi petunjuk dari kesesatan kepada petunjuk dan juga rahmat bagi kaum yang beriman kepada Allah, dan bagi yang mengerjakan amalan sesuai dengan syariatNya. Allah mengkhususkan mereka dengan al Quran atau al Drikir daripada selain mereka karena sesunggubnya mereka adalah orangorang yang mengambil manfaat (dengan al Driker/ al Quran itu).

Ahmad bin Mustafa al Maraghi dalam menafsirkan ayat ini menyebukan bahwa sesungguhnya Allah SW'T. telah menjelaskan kepada mereka (orang-orang kafir) sebuah kitab yang sempurna keterangannya, yaitu al-Qur'an. Allah jelaskan ayat-ayatNya dengan penjelasan berdasarkan ilmuNya tentang ilmu dan amal yang diperlukan oleh orang-orang mukallaf, yang dapat mensucikan jiwa dan membersihkan hati mereka. Dan Allah SWT. menjadikan al-Quran itu jalan kebahagiaan dalam kehidupan di dunia maupun di akhirat, disamping sebagai petunjuk dan rahmat bagi orang yang beriman kepada al-Qur'an dengan iman yang membangkitkannya untuk mengamalkan apa yang diperintahkan kepadanya dan menjauhi apa yang dilarang. ${ }^{24}$

Allah Ta'ala memberitahukan alasanNya yang diberikan kepada orangorang musyrik, yaitu berupa pengutusan para rasul dan pemberian al-Kitab kepada mereka. Yaitu kitab yang memberikan penjelasan secara rinci dan jelas. Yang demikian itu seperti disebutkan pada firmanNya:

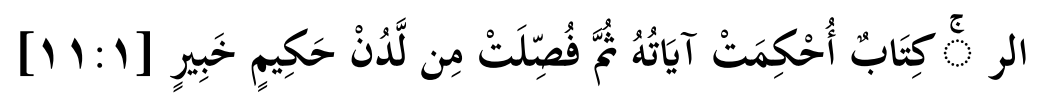

${ }^{23}$ Sholeh ibn Abdul Azis et al, Tafsir al-Muyassar, hlm.157

${ }^{24}$ Ahmad Mustafa al-Maraghi, Tafsir al-Maraghi, hlm. 292-293 
Alif laam raa, (inilab) suatu kitab yang ayat-ayatnya disusun dengan rapi serta dijelaskan secara terperinci, yang diturunkan dari sisi (Allah) Yang Maba Bijaksana lagi Maha Tabu.

Menurut Hamka dalam tafsirnya, bahwa di dalam ayat diterangkan bahwa Kitab itu diturunkan dan diberi pula penjelasan. Segala masalah alQur'an dijelaskan oleh rasul, baik dengan perkataannya ataupun dengan perbuatannya. Duapuluh tiga tahun: Tigabelas tahun di Makkah dan sepuluh tahun di Madinah, bukanlah masa yang singkat buat memberi penjelasan. Lebih lanjut, Hamka menuliskan sebagai berikut:

Bahkan sebagian besar ayat turun ialah karena timbul satu masalah, atau menjawab satu pertanyaan. Terutama sekali di tiap-tiap keterangan ayat itu senantiasa ada penjelasan tentang Tuhan dan sifatNya, tentang tauhid dan bahaya syirik, sejelas-jelasnya. Kemudian dijelaskan pula tentang ibadat, sejak dari wudhu' sampai kepada sembahyangnya. Tentang puasa, zakat dan haji. Dan diterangkan pula di dalam ayat bahwa penjelasan itu ialah dengan dasar ilmu pengetahuan yang diterima oleh akal, sebab dasarnya ialah ilmu. ${ }^{25}$

\section{Tafsir Kata Ilmu}

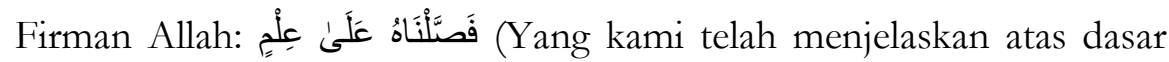
pengetahuan Kami). Kepada orang yang berilmu. Maksudnya, menurut tafsir Ibn Katsir, bahwa berdasarkan ilmu yang berasal dari Allah yang telah dijelaskanNya secara terperinci. Penggalan ayat tersebut sebagaimana firmanNya dalam surah an-Nisaa (4) ayat 166: بَنَزَلَهُ بِعِلْمِهِ (Allah menurunkannya [al-Kitab] dengan ilmuNya). ${ }^{26}$

\section{HASIL DAN DISKUSI}

\section{Keutamaan Ilmu Dan Orang Yang Berilmu}

Diantara bentuk keutamaan ilmu maupun orang yang berilmu, maka di dalam al-Qur'an maupun hadits diberikan sifat-sifat yang baik baginya, antara lain:

\section{Ahl al-'Ilm disebut juga sebagai ahl adz-dzikr}

${ }^{25}$ Hamka, Tafsir Al-Ažbar, Juzu' 4, hlm. 2386

26 Abdullah bin Muhammad Alu Syaikh, Lubaabut Tafsir Min Ibni Katsiir, jilid 1, hlm. 


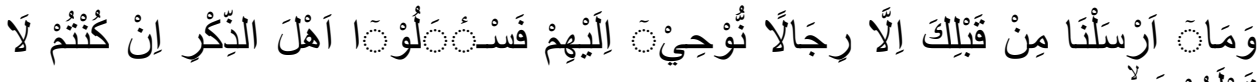

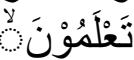

"Dan Kami tidak mengutus sebelum engkau (Muhammad), melainkan orang laki-laki yang Kami beri wahyu kepada mereka; maka bertanyalah kepada orang yang mempunyai pengetahuan jika kamu tidak. mengetahui." (Q.S. An-Nabl [16] : 43)

Bahwasanya Allah Subhanahu Wata'ala memerintahkan manusia untuk bertanya dan merujuk kepada ahlu Az-Zikr (apabila ada perkaraperkara yang mereka tidak mengetahuinya), dan yang dimaksud dengan $A b l u$ Az-Ziker adalah ahlu al-'Ilmi (orang yang mengetahui) apa yang telah diturunkan kepada para nabi. ${ }^{27}$

\section{Orang berilmu akan menjadi penghuni syurga}

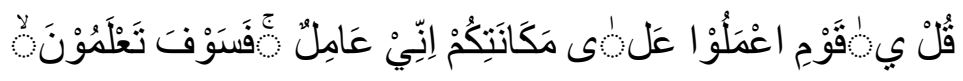

Katakanlab: "Hai kaumku, Bekerjalah sesuai dengan keadaanmu, Sesunggubnya aku akan bekerja (pula), Maka kelak kamu akan mengetabui. (Qs. Az-Zumar: 39)

Allah Ta'ala menolak persamaan antara orang yang berilmu dengan orang yang tidak berilmu sebagaimana halnya Dia menolak persamaan antara penghuni surga dengan penghuni neraka. Ini menunjukkan tentang puncak dari keutamaan dan kemulian orang yang berilmu. ${ }^{28}$

Diantara perbedaan orang yang berilmu dengan orang yang tidak berilmu, adalah sebagaimana Rasulullah SAW bersabda :

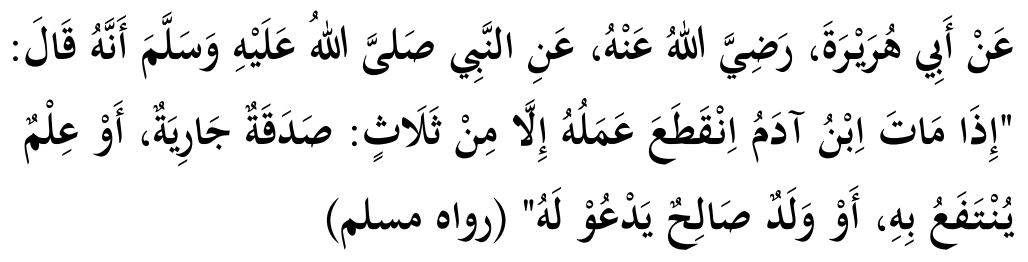

${ }^{27}$ Al-Imam Ibnu Qoyyim Al-Jauziyyah, Mausu'ah Al-'Amal Al-Kaamilah, Darul Wafa', hlm. 147

${ }^{28}$ Yazid Abdul Qodir Jawaz, Menuntut Ilmu Jalan Menuju Surga, Jakarta: Pustaka AtTaqwa, hlm.56. 
Dari Abu Hurairah R.A, dari Nabi SAW bahwasanya dia bersabda : "Apabila anak adam meninggal semua amalnya terputus kecuali tiga perkara: Shadaqah jariyah, atau ilmu yang bermanfaat atau anak shaleh yang mendoakannya". (HR. Muslim).

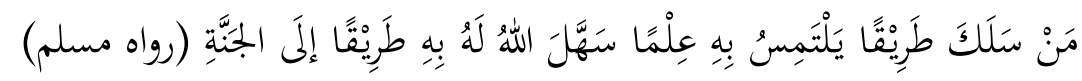

"Barang siapa menempub suatu jalan untuk menggapai ilmu, maka Allah memudabkan baginya jalan menuju surga." (HR. Muslim no. 2699)

Hadits di atas menunjukkan bahwa menuntut ilmu memudahkan jalan menuju surga. Dan Jalan menuju surga mempunyai dua makna. Pertama, Allah akan memudahkan memasuki surga bagi tholibul ilmi yang tujuannnya untuk mencari keridhoaan Allah semata dalam mendapatkan ilmu, mengambil manfaat dari ilmu syar'i dan mengamalkan konsekuensinya. Kedua, Allah akan memudahkan baginya jalan ke surga pada hari kiamat ketika melewati "shirath" dan dimudahkan dari berbagai ketakutan, baik sebelum maupun sesudahnya. ${ }^{29}$

\section{Ilmu sebagai kehidupan dan cahaya}

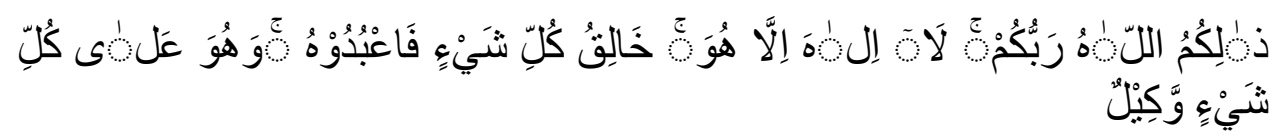

Dan Apakah orang yang sudah mati kemudian Dia Kami bidupkan dan Kami berikan kepadanya cabaya yang terang, yang dengan cabaya itu Dia dapat berjalan di tengah-tengah masyarakat manusia, serupa dengan orang yang keadaannya berada dalam gelap gulita yang sekali-kali tidak dapat keluar dari padanya? Demikianlah Kami jadikan orang yang kafir itu memandang baik apa yang telah mereka kerjakan. (Qs. Al-An'am: 122)

Al-Hafidz Ibnu Katsir rahimahullah berkata : "Ini merupakan sebuah misal yang telah Allah Ta'ala umpamakan untuk orang mu'min yang dulunya mati (berada dalam kesesatan, kehancuran serta kebingungan), kemudian dibidupkan oleh Allah dengan iman, dan memberikan petunjuk serta taufik kepadanya dalam it-tiba' para rasul-Nya. \{Dan kami berikan kepadanya cahaya yang terang, yang dengan cahaya itu dia dapat berjalan di tengah-tengah

${ }^{29}$ Qawaa'id Wa Fawaa'id Minal Arbaiin An-Nawawiyyah, hlm.316-317

30 Maksudnya ialah orang yang telah mati hatinya Yakni orang-orang kafir dan sebagainya. 
masyarakat manusia\}, yaitu : dengannya ia mendapatkan petunjuk, bagaimana ia bertindak serta bersikap. Dan cahaya yang dimaksud di sini adalah AlQur'an, sebagaimana yang telah diriwayatkan oleh Al-'Aufii dan Ibnu Abi Tholhah, dari Ibnu Abbas sedangkan As-Suddii berpendapat : cahaya yang dimaksud di sini adalah Islam. Dan itu semuanya benar. ${ }^{31}$

Ibnu Qoyyim Al-Jauziyah rabimabullah berkata :"Sesungguhnya ilmu adalah kehidupan dan cahaya, sedangkan kebodohan adalah kematian dan kegelapan. Semua kejahatan dan keburukan penyebabnya ialah tidak adanya kehidupan dan cahaya". ${ }^{32}$

\section{Amal tanpa ilmu akan menyebabkan tersesat}

Amal perbuatan tanpa ilmu seperti perjalanan tanpa petunjuk jalan.

Ibnu Taimiyah berkata: "Barang siapa meninggalkan petunjuk jalan, ia tersesat di jalan dan tidak ada petunjuk jalan kecuali apa yang dibawa oleh Rasulullah." Demikian pula Al Imam Al-Hasan Bashri berkata: "Orang yang beramal tanpa ilmu seperti orang yang berjalan tidak diatas jalan yang semestinya. Orang yang beramal tanpa ilmu lebih banyak merusak daripada memperbaiki." 33

Sesungguhnya ilmu adalah panglimanya, sedang amal pengikutnya. Setiap amal yang tidak berpedoman kepada ilmu dan tidak mengikuti bimbingan ilmu, maka amal itu tidak berguna bagi pelakunya bahkan dapat membahayakannya". Sebagian ulama salaf berkata :"Barang siapa beribadah kepada Allah tanpa ilmu, maka apa yang ia rusak lebih banyak dari apa yang ia perbaiki". Jadi, ilmu adalah tolok ukur dan standar utama. ${ }^{34}$

\section{Malaikat ridha kepada para pencari ilmu}

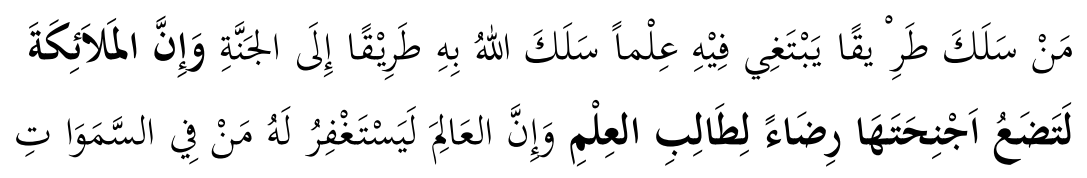

${ }^{31}$ Tafsir Ibnu Katsir, Kairo: Darul Hadits, Jilid 2, hlm. 214.

32 Ibnu Qoyyim Al-Jauziyah, Buah Ilmu, Terj. Jakarta: Purtaka Azzam, hlm.18.

${ }^{33}$ Ibnu Qoyyim Al-Jauziyah, Buab Ilmu, Terj. Jakarta: Purtaka Azzam, hlm. 79

34 Anis Ahmad Karzun, 13 Kiat Mencari Ilmu Menuai Berkah. 


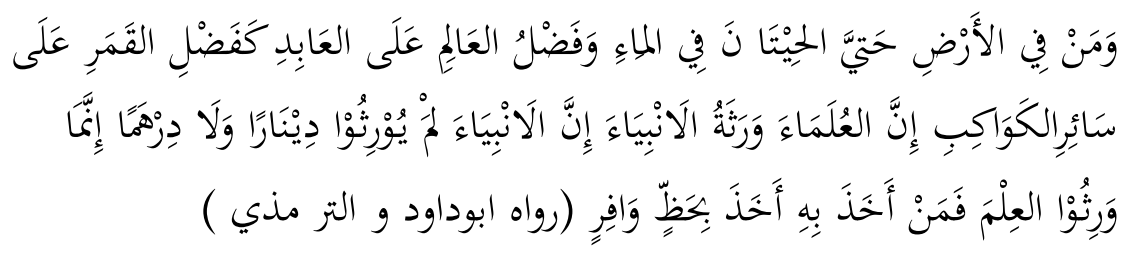

"Barang siapa melewati salah satu jalan dengan tujuan mencari ilmu maka Allah membuka dengannya jalan menuju syurga dan sesunggubnya para Malaikat meletakean sayap-sayapnya karena ridha kepada para pencari ilmu.Sesunggubnya apa saja yang ada di bumi hingga ikan-ikan di lautan rilmu itu dimintakan ampunan oleb siapa saja yang ada di langit,. Kelebihan orang berilmu atas orang beribadah adalah seperti kelebihan bulan atas bintang. Sesunggubnya para ulama adalah pewaris para Nabi-nabi sesunggubnya para Nabi tidak mewariskan dinar dan tidak pula dirham, namun mereka mewariskan ilmu. Maka barang siapa mendapatkanya, ssunggub ia mendapatkan keberuntungan yang besar." (HR.Abu Dawud dan Turmidri)

Beragam makna arti dari (meletakkan sayap-sayapnya), diantaranya : Tawadhu' kepada Tholibul Ilmi, mebersamai, menghormati serta menolongnya sehingga sampai pada tujuannya. ${ }^{35}$

Jika seorang hamba menuntut ilmu, maka pada dasarnya dia berusaha mencari sesuatu yang membawa kebaikan bagi hamba-hamba Allah yang lain. Oleh karena itu, dia dicintai para malikat dan dihormati mereka sehingga mereka meletakkan sayap-sayapnya karena ridha, cinta, dan hormat. ${ }^{36}$

\section{Aqidah (Tawhid) Sebagai Fondasi Epistemologi Islam}

Aqidah berasal dari kata 'aqd yang berarti pengikatan. Seperti kata i'taqadtu kadra (saya beri'tiqad begini). Maksudnya, mengikatkan hati terhadap hal tersebut. Aqidah merupakan perbuatan hati, yaitu kepercayaan hati dan pembenarannya kepada sesuatu. Secara istilah aqidah berarti beriman kepada Allah, para malaikat-Nya, kitab-kitab-Nya, para rasul-Nya, kepada hari akhir

35 Syekh Badruddin, Tadzkiratu As-Saami' Wal Mutakallim Fii Adabil 'Aliim Wal Muta'allim, Darul Kutub Al-Imiyyah, hlm.8

${ }^{36}$ Yazid bin Abdul Qadir Jawas, Menuntut Ilmu Jalan Menuju Surga, Jakarta: Pustaka at-Taqwa, hlm.50 
dan kepada qadha' dan qadar. ${ }^{37}$ Sedangkan menurut Ismail Raji Al-Faruqi, iman adalah sesuatu yang terjadi kepada seseorang, dimana kebenaran atau fakta dari sebuah objek tampil di depan wajahnya dan meyakinkannya tanpa ada keraguan tentang kebenarannya. Ia bagaikan kebenaran kesimpulan geometri, dimana premis yang terdahulu mendorong seseorang untuk mengetahui tentang kebenaran konklusinya tanpa bisa menghindar. ${ }^{38}$

\section{Epistemologi Islam}

Epistemologi Islam ialah teori/falsafah ilmu berdasarkan ajaran Islam. Ia bukanlah semata-mata persoalan bersifat falsafah malah merupakan tindakbalas terhadap persoalan-persoalan bersifat kehidupan, masyarakat dan kenegaraan yang merangkum keseluruhan kehidupan dunia dan akhirat.

Sebagai sebuah teori yang dihasilkan dari pemikiran yang mendalam maupun melalui usaha-usaha penelitian manusia maka ia tentu mengandalakan akal yang dianugerahkan oleh Allah kepada manusia. AlQur'an juga memberikan peluang yang luas bahwa akal dapat dimaksimalkan untuk mentadabburi ayat-ayat qauliyah maupun ayat-ayat kauniyah.

Dalam beberapa ayat, Allah mengecam orang yang enggan menggunakan akal dan panca indera mereka untuk berpikir, bahkan menyebut mereka sebagai "seburuk-buruk binatang melata di dunia ini: Qs. Al-Anfal: 22

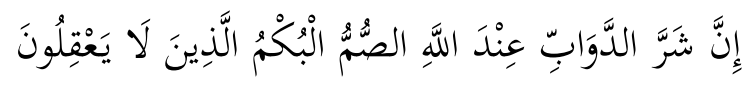

Sesungguhnya binatang (makbluk) yang seburuk-buruknya pada sisi Allah ialab; orangorang yang pekak dan tuli $i^{39}$ yang tidak mengerti apa-apapun.

Akan tetapi disisi lain, sesungguhnya akal manusia memiliki kemampuan yang cukup terbatas. Sebagaimana Allah menyebutkan di dalam surat Al-Isra ayat 85.

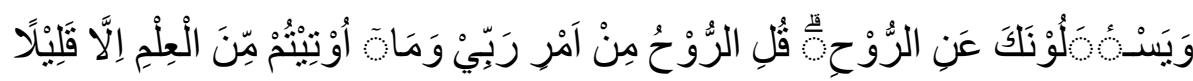

37 Shalih Bin Fauzan Abdullah Al Fauzan, Kitab Tauhid, Jakarta: Penerbit Atase Agama, hlm. 3. Lihat juga: Muhammad Bin Ibrahim Al-Hamd, Aqidah Abl as-Sunnab wa alJama'ab;Mafhumuha-Khashaishuha-Khashaishu Abliha, Arab Saudi: Dar Ibn Khuzaimah, hlm. 8

38 Isma'il Raji al-Faruqi, al-Tawbid: Its Implications for Thought and Life (Herndon, Virginia: International Institute of Islamic Thought, 1995), 41.

39 Maksudnya: manusia yang paling buruk di sisi Allah ialah yang tidak mau mendengar, menuturkan dan memahami kebenaran. 
Artinya: Dan mereka bertanya kepadamu tentang roh. Katakanlab: "Roh itu Termasuk urusan Tuban-ku, dan tidaklah kamu diberi pengetahuan melainkan sedikit". (QS. AlIsra ayat 85 )

Oleh karenanya manusia tidak boleh hanya mengandalkan akal dan logika semata untuk mendapatkan kebenaran, tetapi ia harus menggali kebenaran dan ilmu dari sumber yang absolut, sumber yang tidak pernah keliru, yakni Al-Qur'an yang dilandasi dengan tauhid yang kokoh (yakin sepenuhnya) kepada kebenaran Allah Swt.

Ayat- ayat tentang ilmu yang telah tersebut di atas juga menunjukkan urgensi pemurnian pemahaman terhadap akidah yang menjadi pondasi dasar bangunan keislaman seorang Muslim secara menyeluruh dari berbagai aspeknya. Termasuk dalam hal ini adalah pemahaman akan konsep tauhid asma wa shifat, tentang keagungan nama-nama sifat dan perbuatan Allah Subhanahu Wa Ta'ala yang dipahami dengan benar sesuai dengan pengertian dan makna yang dikehendakiNya melalui penjelasan para Ulama Ahli Tafsir.

Sebagaimana telah diketahui dari metode da'wah Rasulullah Shallallahu 'Alayhi Wasallam yang memperhatikan pokok pertama atau perkara yang paling penting yaitu aqidah, ibadah dan akhlak. Bahkan semua nabi memulai dakwahnya dengan aqidah ini. Sebagaimana firmanNya:

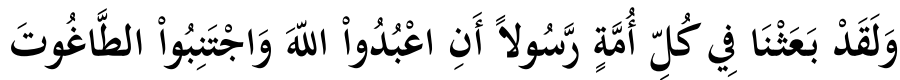

"Dan sesunggubnya Kami telah mengutus rasul pada tiap-tiap umat (untuk menyerukan): "Sembablah Allah (saja), dan jaubilab thagbut". [QS. An-Nabl:36]

Ini menunjukkan dengan tegas bahwa sesuatu yang paling penting untuk di prioritaskan oleh para pendidik dan da'i Islam adalah da'wah kepada tauhid secara komprehensif. Sejalan dengan pengertian ayat di atas adalah makna firman Allah Subbanabu wa Ta'ala:

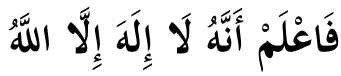

"Maka ketabuilah, bahwa sesungubnya tidak ada sesembahan (yang berbak diibadabi) melainkan Allab". [QS. Mubammad: 19]

\section{KESIMPULAN}

Islam menjunjung tinggi ilmu, baik ilmu itu sendiri maupun orangorang yang menekuni ilmu, mengerahkan tenaga dan waktunya untuk menggali ilmu. Karena begitu pentingnya ilmu sehingga Allah menyebutkan 
kata ini sampai beratus-ratus kali. Bagi Islam, sumber ilmu yang paling benar adalah dari al-Qur'an dan hadits yang shahih, sehingga bagi seorang muslim pun harus menyandarkan ilmu nya kepada keduanya dan melandasinya dengan konsep aqidah atau tauhid yang kokoh kepada Allah sebagai sumber ilmu yang absolut.

\section{DAFTAR PUSTAKA}

Abdullah bin Muhammad bin 'Abdurrahman bin Ishaq Alu Syaikh, Lubaabut Tafsir Min Ibni Katsiir (Terj.), jilid 1, Jakarta: Pustaka Imam Syafi'i, 2012.

Al Fauzan, Shalih Bin Fauzan Abdullah, Kitab Tauhid, Jakarta: Penerbit Atase Agama.

al-Baghdadi, Abdul Qohir, Al-Farqu Bainal Firaq, Beirut: Dar alKutub al-Ilmiyah, tanpa tahun.

al-Faruqi, Isma'il Raji, al-Tawbid: Its Implications for Thought and Life (Herndon, Virginia: International Institute of Islamic Thought, 1995).

Al-Hamd, Muhammad Bin Ibrahim, Aqidah Abl as-Sunnah wa alJama'ab;Mafhumuba-Khashaishuha-Khashaishu Abliha, Arab Saudi: Dar Ibn Khuzaimah.

Al-Jauziyah, Ibnu Qoyyim, Buah Ilmu, Terj. Jakarta: Purtaka Azzam. Kaamilah, Darul Wafa'.

Al-Imam Ibnu Qoyyim, Mausu'ah Al-'Amal Al-

al-Maraghi, Ahmad Mustafa, Tafsir al-Maraghi, Semarang: CV. Toha Putra, 1992.

Alu Syekh, Sholeh ibn Abdul Azis bin Muhammad, et al, Tafsir alMuyassar, Percetakan al-Qur'an Kerajaan Saudi Arabiah, 1430 H/ 2009 M.

Azis, Sholeh ibn Abdul, et al, Tafsir al-Muyassar.

Badruddin, Tad₹kiratu As-Saami' Wal Mutakallim Fii Adabil 'Aliim Wal Muta'allim, Darul Kutub Al-Ilmiyyah. 2003.

Hamka, Tafsir Al-Az̧ar, Juгu’ 3, Kerjaya Printing Industries Pte Ltd, 2003.

--------, Tafsir Al-Ažbar, Jигu’ 4, Kerjaya Printing Industries Pte Ltd, 
Hasib, Kholili, Konsep Ilmu dalam Islam dan Tantangan Ghazwul Fikri, dikutip dari link: http://inpasonline.com/new/konsep-ilmu-dalam-islamdan-tantangan-ghazwul-fikri/

Ibnu 'Asyur, At-Tahrir wat Tanwir Karya

Jawas, Yazid bin Abdul Qadir, Menuntut Ilmu Jalan Menuju Surga, Jakarta: Pustaka at-Taqwa.

Karzun, Anis Ahmad, 13 Kiat Mencari Imu Menuai Berkah.

Tafsir Ibnu Katsir, Kairo: Darul Hadits, Jilid 2.

Wan Daud, Wan Mohd Nor, Epistemologi Islam dan Tantangan Pemikiran Umat,dalam Jurnal Islamia No. 5 Thn II April-Juni 2005. 